\title{
Concomitant hepatic tuberculosis and hepatocellular carcinoma: a case report and review of the literature
}

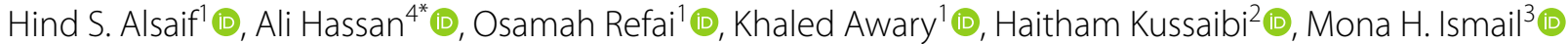 \\ and Ibrahim Alghnimi ${ }^{1}$ (1)
}

\begin{abstract}
Background: Hepatocellular carcinoma (HCC) is the most common primary liver malignancy that is strongly associated with chronic liver disease. Isolated hepatic tuberculosis is an uncommon type of tuberculosis. Concomitant occurrence of both conditions is extremely rare.

Case presentation: We report the case of a 47-year-old man who presented with fever and abdominal pain for 3 months prior to presentation. He reported a history of anorexia and significant weight loss. Abdominal examination revealed a tender, enlarged liver. Abdominal computed tomography $(C T)$ demonstrated a solid heterogeneous hepatic mass with peripheral arterial enhancement, but no venous washout, conferring a radiological impression of suspected cholangiocarcinoma. However, a CT-guided biopsy of the lesion resulted in the diagnosis of concomitant HCC and isolated hepatic tuberculosis.

Conclusion: A rapid increase in tumor size should draw attention to the possibility of a concomitant infectious process. Clinicians must have a high index of suspicion for tuberculosis, especially in patients from endemic areas, in order to initiate early and proper treatment.
\end{abstract}

Keywords: Hepatocellular carcinoma, Epatic tuberculosis, Neoplasms, Case reports

\section{Background}

Hepatocellular carcinoma $(\mathrm{HCC})$ is a primary liver malignant tumor that is a leading cause of cancer-related mortality worldwide [1]. It often develops in the setting of chronic liver disease, and it is estimated that more than $70 \%$ of cases are related to chronic infection from hepatitis B or C viruses [2]. It is very unusual for $\mathrm{HCC}$ to arise in a patient with a non-cirrhotic liver in the absence of risk factors [3].

Tuberculosis is a significant disease worldwide. Abdominal tuberculosis occurs in $5 \%$ of all cases of

\footnotetext{
*Correspondence: alihy8@gmail.com

${ }^{4}$ Department of Radiology, Salmaniya Medical Complex, Manama, Bahrain

Full list of author information is available at the end of the article
}

tuberculosis [4]. However, isolated hepatic tuberculosis is a rare form of extrapulmonary tuberculosis. An accumulating body of evidence has indicated the role of infectious agents in oncogenesis. Several Nobel prizes have been awarded to scientists for their work on the relationship between infectious agents and cancer [5]. It is reported that up to $20 \%$ of all cancers worldwide are linked to infectious agents [6].

Although the association between tuberculosis and malignancies was first described approximately 200 years ago [7], the co-existence of hepatic tuberculosis and HCC has been reported in a few cases. Herein, we report a middle-aged man diagnosed with $\mathrm{HCC}$ and isolated tuberculosis. 


\section{Case presentation}

A 47-year-old Indian man presented to the emergency department with a history of fever and abdominal pain for 3 months. The fever was low-grade, intermittent, relieved by antipyretics, and not associated with chills or rigor. Abdominal pain was experienced in the right upper quadrant, sharp in character, and not related to meal consumption. He also reported a cough, anorexia, and unintentional weight loss of $10 \mathrm{~kg}$ during the same period. There was no history of vomiting, altered bowel motion, or changes in stool or urine color. A review of other systems revealed unremarkable findings. His medical history was remarkable for diabetes mellitus, which was treated with an oral antidiabetic agent. He had no history of having undergone surgeries previously. He reported no tobacco smoking, alcohol consumption, or intravenous drug abuse. Notably, he reported no recent travel or consumption of unpasteurized dairy products.

On presentation, he was not icteric or pale. He had a pulse rate of $119 \mathrm{bpm}$, and his other vital signs were within normal limits. Abdominal examination revealed a tender, enlarged liver with a span of $15 \mathrm{~cm}$, and the spleen was palpable $2 \mathrm{~cm}$ below the left costal margin. The results of the laboratory studies are summarized in Table 1.

Abdominal ultrasonography revealed a solid lesion with heterogeneous echogenicity in the right lobe of the liver in a normal liver background. The mass was further characterized by dedicated contrast-enhanced computed tomography (CT) of the liver in four phases (non-contrast, arterial, portovenous, and delayed phase), which revealed a heterogeneous solid mass measuring $8.5 \mathrm{~cm} \times 6.5 \mathrm{~cm} \times 5.2 \mathrm{~cm}$ with peripheral arterial enhancement, internal hypodensity, and no venous or delayed washout. In addition, multiple small satellite lesions were observed throughout the liver. Multiple enlarged lymph nodes were found in the portohepatic, para-aortic, and retrocaval groups with no evidence of thoracic metastases. Dilatation of the left lobe biliary radicals was also observed. Considering that venous washout was not observed, which is a hallmark for the diagnosis of $\mathrm{HCC}$, the radiological impression was of suspected cholangiocarcinoma (Fig. 1).

The patient continued to experience multiple episodes of fever during his hospital stay. Percutaneous transhepatic biliary drainage was then performed, as the patient was presumed to have cholangitis due to an obstructive lesion. Moreover, the patient underwent an ultrasoundguided biopsy of the liver lesion, and histopathological examination revealed a poorly differentiated HCC. The tumor cells showed immunohistochemical positivity for CK19, CK8, CK7, AFP, and pCEA and negativity for CK20, CD10, and HepPar1 (Fig. 2).
Table 1 Summary of the results of laboratory findings

\begin{tabular}{|c|c|c|c|}
\hline Laboratory investigation & Unit & Result & Reference range \\
\hline Hemoglobin & $\mathrm{g} / \mathrm{dL}$ & 7.4 & $13.0-18.0$ \\
\hline White blood cell & $1000 / \mathrm{mL}$ & 26.8 & $4.0-11.0$ \\
\hline Platelet & $1000 / \mathrm{mL}$ & 639 & $140-450$ \\
\hline $\begin{array}{l}\text { Erythrocyte sedimenta- } \\
\text { tion rate }\end{array}$ & $\mathrm{mm} / \mathrm{hr}$ & 119 & $0-20$ \\
\hline C-reactive protein & $\mathrm{mg} / \mathrm{dL}$ & 24.1 & $0.05-3.0$ \\
\hline Total bilirubin & $\mathrm{mg} / \mathrm{dL}$ & 1.1 & $0.2-1.2$ \\
\hline Albumin & $\mathrm{g} / \mathrm{dL}$ & 2.5 & $3.4-5.0$ \\
\hline Alkaline phosphatase & $U / L$ & 596 & $46-116$ \\
\hline $\begin{array}{l}\text { Gamma-glutamyltrans- } \\
\text { ferase }\end{array}$ & $U / L$ & 294 & $15-85$ \\
\hline Alanine transferase & $U / L$ & 124 & $14-63$ \\
\hline Aspartate transferase & $U / L$ & 41 & $15-37$ \\
\hline Blood urea nitrogen & $\mathrm{mg} / \mathrm{dL}$ & 8 & $7-18$ \\
\hline Creatinine & $\mathrm{mg} / \mathrm{dL}$ & 1.06 & $0.7-1.3$ \\
\hline Sodium & $\mathrm{mEq} / \mathrm{L}$ & 135 & $136-145$ \\
\hline Potassium & $\mathrm{mEq} / \mathrm{L}$ & 3.4 & $3.5-5.1$ \\
\hline Chloride & $\mathrm{mEq} / \mathrm{L}$ & 98 & $98-107$ \\
\hline Hepatitis B core antibody & & Non-reactive & Non-reactive \\
\hline Hepatitis B surface antibody & & Non-reactive & Non-reactive \\
\hline Hepatitis C virus antibody & & Non-reactive & Non-reactive \\
\hline $\begin{array}{l}\text { Carbohydrate antigen } \\
\text { 19-9 }\end{array}$ & $\mathrm{U} / \mathrm{mL}$ & 110.7 & $0-37$ \\
\hline Carcinoembryonic antigen & $\mathrm{U} / \mathrm{mL}$ & 1.9 & $0-3.0$ \\
\hline Alpha fetoprotein & $\mathrm{ng} / \mathrm{mL}$ & 35,297 & $10-15$ \\
\hline
\end{tabular}

The patient received intravenous metronidazole (500 mg every $8 \mathrm{~h}$ ) and imipenem (500 mg every $6 \mathrm{~h}$ ). Intravenous fluconazole ( $400 \mathrm{mg}$ every $24 \mathrm{~h}$ ) was also initiated after the biliary culture exhibited growth of Candida parapsilosis and C. tropicalis. However, the patient did not show any clinical improvement. Abdominal ultrasonography was repeated, which highlighted the progression of the previously identified lesion. Subsequently, abdominal CT revealed that the mass had markedly increased in size compared to that on the initial CT performed 33 days prior, as it measured $11.3 \mathrm{~cm} \times 10.6 \mathrm{~cm} \times 10.6 \mathrm{~cm}$ with a larger central hypodense component (Fig. 3). A co-existing infectious process was suspected because of the rapid increase in the size of the lesion. The tissue obtained from the biopsy was sent for routine bacterial culture, acid-fast bacilli smear, and polymerase chain reaction (PCR) testing. The PCR revealed Mycobacterium tuberculosis despite the negative acid-fast bacilli smear result.

Subsequently, antitubercular therapy comprising rifampicin $(600 \mathrm{mg} /$ day $)$, isoniazid $(300 \mathrm{mg} /$ day $)$, ethambutol (1.2 g/day), and levofloxacin $(500 \mathrm{mg} /$ day $)$ was initiated. Over the following days, a significant clinical 

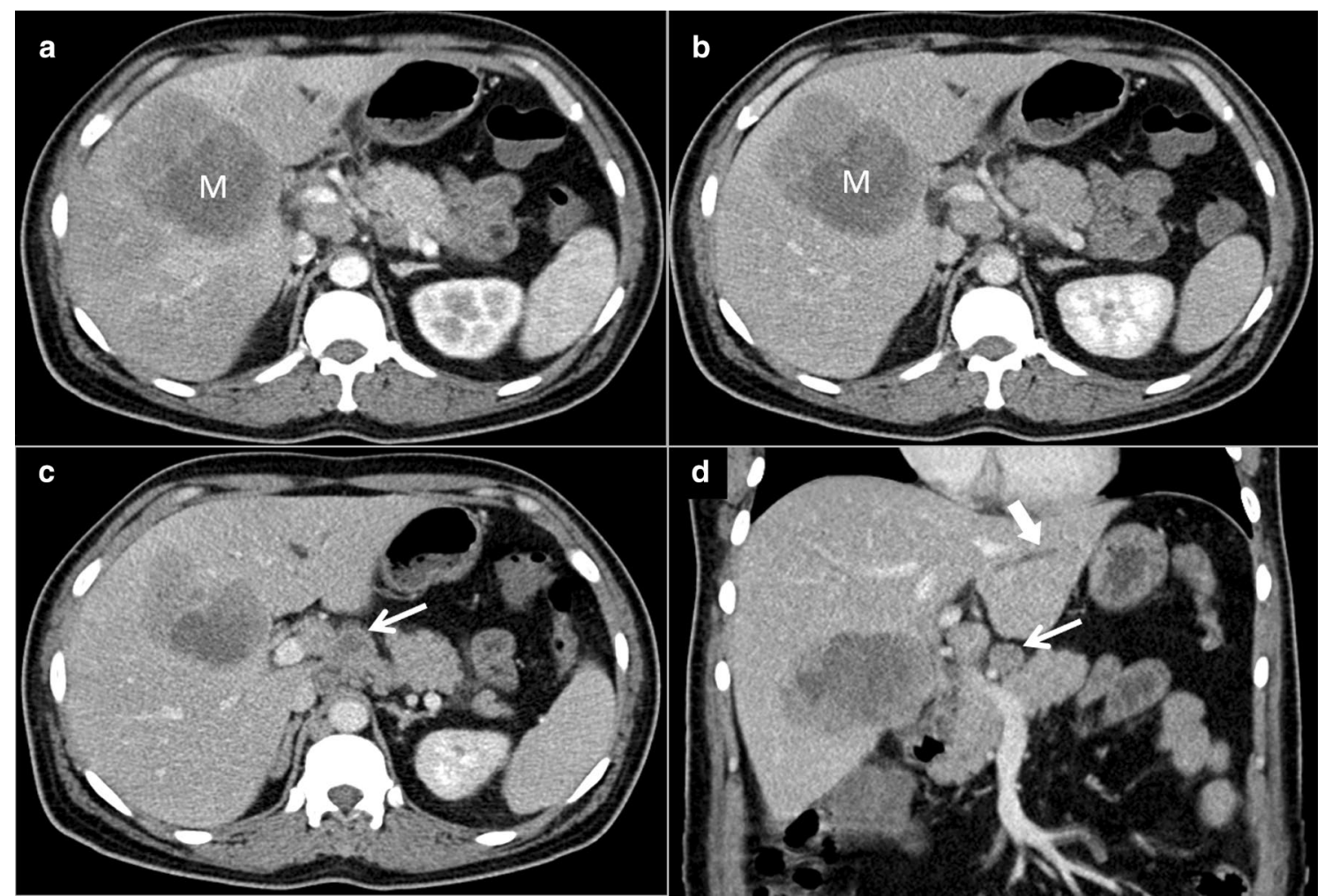

Fig. 1 Contrast-enhanced abdominal computed tomography images acquired on initial presentation (a axial image in the arterial phase; b, c axial images in the venous phase; and $\mathbf{d}$ coronal image in the venous phase) demonstrating a heterogeneous mass (M) with internal hypodensity in segment V (a and $\mathbf{b}$ ). Necrotic lymph nodes (thin arrows in $\mathbf{c}$ and $\mathbf{d}$ ) and mild biliary dilatation (thick arrow in $\mathbf{d}$ ) were noted

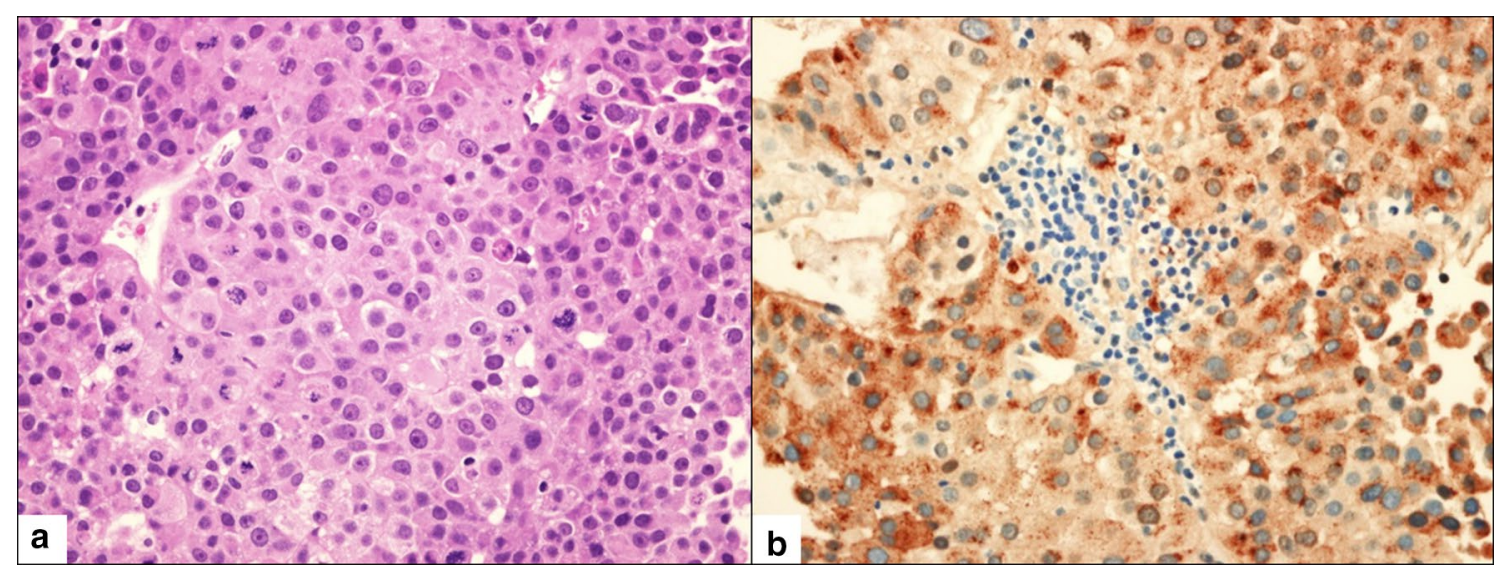

Fig. 2 Microscopic view (H\&E stain, $\times 40$ ) showed moderate-to-prominent cellular and nuclear pleomorphism and hyperchromatism along with frequent abnormal mitoses and apoptotic bodies (a). The immunohistochemistry view demonstrated the expression of alpha-fetoprotein (b). H\&E, hematoxylin and eosin

improvement was evident with resolution of the fever. On discharge, the patient was asymptomatic, and antitubercular treatment was continued. Surgical resection was not planned because the tumor was locally advanced with possible lymph node involvement. The patient decided to continue further management in his home country since he was not medically insured. 


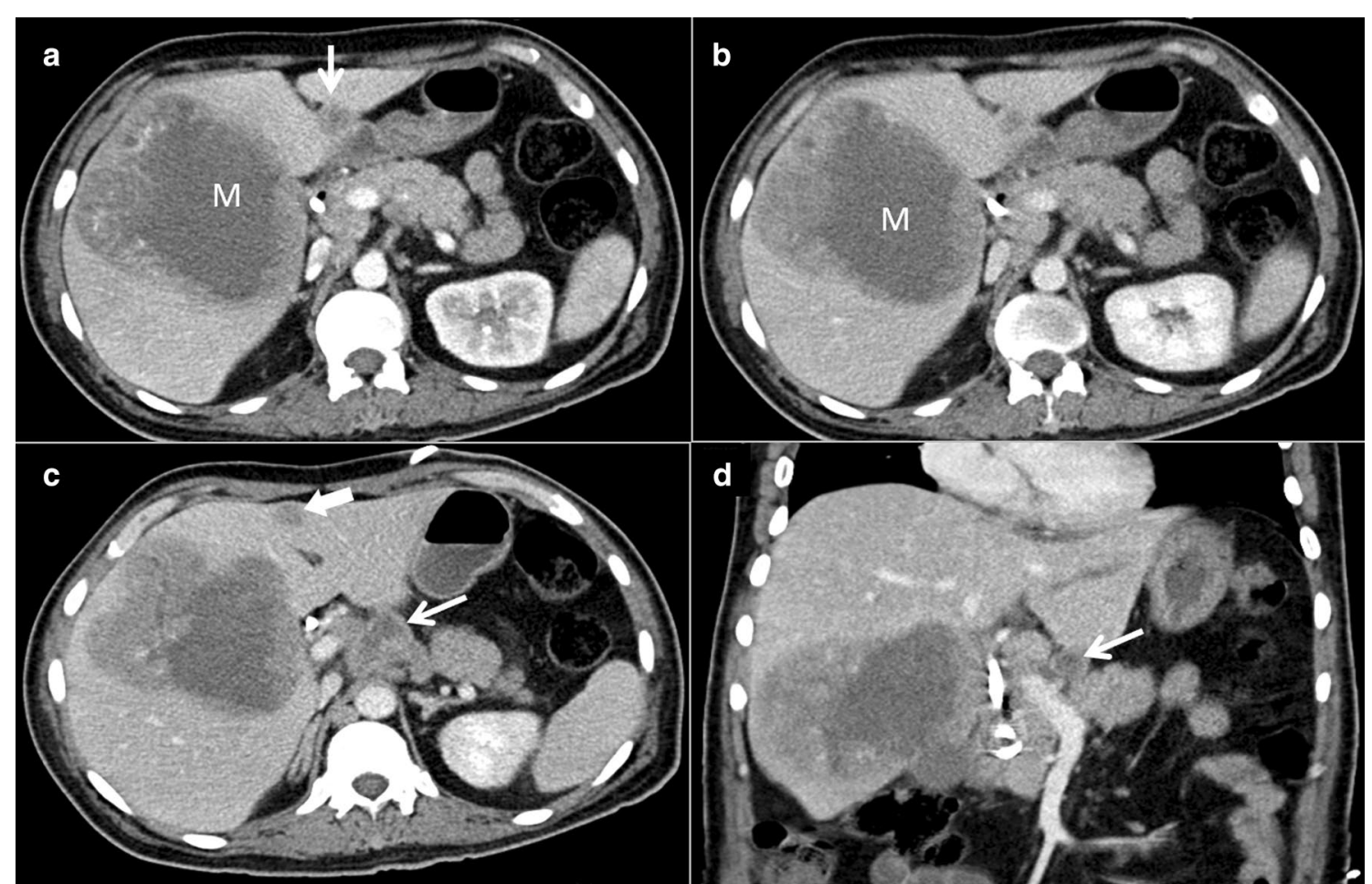

Fig. 3 Contrast-enhanced abdominal computed tomography images acquired 1 month following the initial presentation (a axial image in the arterial phase; $\mathbf{b}, \mathbf{c}$ axial images in the venous phase; and $\mathbf{d}$ coronal image in the venous phase) demonstrating an interval increase in the size of the mass lesion (M) with larger central hypodensities ( $\mathbf{a}$ and $\mathbf{b}$ ). Necrotic lymph nodes (thin arrows in $\mathbf{c}$ and $\mathbf{d}$ ) were observed. A new nodule in the left liver lobe (thick arrow in $\mathbf{c}$ ) and interval increase in the size of the nodule at the falciform ligament (arrow in a) were noted

\section{Discussion}

We report an exceedingly rare case of primary liver malignancy co-existing with isolated hepatic tuberculosis. Only five cases involving conditions similar to this condition have been reported previously. The first case was reported by Wagner in 1861, who discovered HCC and tuberculosis in two separate lesions during autopsy examination [8] (Table 2).

The association between tuberculosis and malignancy may be merely incidental, as both conditions are common. However, there is a growing body of evidence suggesting that mycobacterial infection may play a role in

Table 2 Review of cases of co-existing hepatic tuberculosis and hepatocellular carcinoma

\begin{tabular}{|c|c|c|c|c|c|c|c|}
\hline No. & Year & Author & Age & Gender & Medical history & Clinical presentation & HCC and TB lesions \\
\hline 1 & 1861 & Wagner & NA & NA & NA & Autopsy finding & Different lesions \\
\hline 2 & 1983 & Essop & 70 & Male & Liver cirrhosis & $\begin{array}{l}\text { Vomiting } \\
\text { Abdominal pain }\end{array}$ & Same lesion \\
\hline 3 & 1994 & Yano & 72 & Female & $\begin{array}{l}\text { Diabetes mellitus } \\
\text { Hypertension } \\
\text { Pleurisy }\end{array}$ & Asymptomatic & Same lesion \\
\hline 4 & 2012 & Limaiem & 73 & Female & $\begin{array}{l}\text { Hypertension } \\
\text { Hepatitis C }\end{array}$ & Abdominal pain & Same lesion \\
\hline 5 & 2019 & Shah & 70 & Male & $\begin{array}{l}\text { Diabetes mellitus } \\
\text { Hypertension } \\
\text { Hepatitis C }\end{array}$ & $\begin{array}{l}\text { Decreased appetite } \\
\text { Weight loss }\end{array}$ & Same lesion \\
\hline 6 & Current case & & 47 & Male & Diabetes mellitus & $\begin{array}{l}\text { Fever } \\
\text { Abdominal pain }\end{array}$ & Same lesion \\
\hline
\end{tabular}


carcinogenesis [9]. For example, $M$. tuberculosis has been shown to have the ability to induce DNA damage via the production of reactive oxygen species [10]. Moreover, the organism may exhibit increased expression of BCL2, which has anti-apoptotic activity [11]. An experimental study has shown that the purified protein derivative of tuberculin can upregulate the expression of vascular endothelial growth factor in lymphocytes, which has significant angiogenic and mitogenic properties [12]. Lastly, it is well known that chronic inflammation, as in mycobacterial infection, is a potential factor in the development of cancers and metastatic spread [13]. Gastric lymphoma is a well-established example in which chronic inflammation, as induced by Helicobacter pylori infection, has a causal link with carcinogenesis [14].

The diagnosis of HCC and hepatic tuberculosis was not straightforward in the present case. For example, the radiological findings of hepatic lesion were not typical of HCC. The presence of arterial enhancement in the hepatic lesion and subsequent washout in the portal or delayed phases are considered hallmark imaging features of HCC [15]. However, an atypical appearance of HCC is not uncommon and is reported in approximately $40 \%$ of all cases [16]. The presentation of tuberculosis was also atypical in the present case since the chest X-ray findings were normal and the acid-fast bacilli smear result was negative. This case was a useful example of the role of PCR as a rapid and reliable tool for the diagnosis and management of tuberculosis [17].

The median doubling time of hepatocellular lesions is 117 days [18]. In the present case, the volume of the lesion nearly doubled within 27 days, as estimated mathematically [19], which was a rapid increase and led us to suspect the presence of a co-existing infection.

\section{Conclusion}

A rapid increase in tumor size should draw attention to the possibility of a concomitant infectious processes. Clinicians must have a high index of suspicion for tuberculosis, especially in patients from endemic areas, in order to initiate early and proper treatment. Further work is needed to better understand the role of tuberculosis in malignancies.

\section{Abbreviations}

CT: Computed tomography; HCC: Hepatocellular carcinoma; PCR: Polymerase chain reaction.

\section{Acknowledgements}

Not applicable.

\section{Authors' contributions}

HA: edited the manuscript and prepared the radiological images; AH: drafted the manuscript and reviewed the literature; OR: reviewed the literature; KA: edited the manuscript; HK: prepared the pathological images; MI: responsible for the patient care; IA: edited the manuscript. All authors read and approved the final manuscript.

\section{Funding}

This research received no specific grant from any funding agency in the public, commercial, or not-for-profit sectors.

\section{Availability of data and materials}

Not applicable.

\section{Ethics approval and consent to participate}

Not applicable.

\section{Consent for publication}

Written informed consent was obtained from the patient for publication of this report and any accompanying images.

\section{Competing interests}

The authors declare that they have no competing interests.

\section{Author details}

${ }^{1}$ Department of Radiology, King Fahd Hospital of the University, Imam Abdulrahman Bin Faisal University, Al-Khobar, Saudi Arabia. ${ }^{2}$ Department of Pathology, King Fahd Hospital of the University, Imam Abdulrahman Bin Faisal University, Al-Khobar, Saudi Arabia. ${ }^{3}$ Department of Internal Medicine, King Fahd Hospital of the University, Imam Abdulrahman Bin Faisal University, Al-Khobar, Saudi Arabia. ${ }^{4}$ Department of Radiology, Salmaniya Medical Complex, Manama, Bahrain.

Received: 30 August 2020 Accepted: 16 December 2020

Published online: 02 January 2021

\section{References}

1. Ferlay J, Shin HR, Bray F, Forman D, Mathers C, Parkin DM. Estimates of worldwide burden of cancer in 2008: GLOBOCAN 2008. Int J Cancer. 2010;127(12):2893-917.

2. Maucort-Boulch D, de Martel C, Franceschi S, Plummer M. Fraction and incidence of liver cancer attributable to hepatitis B and C viruses worldwide. Int J Cancer. 2018;142(12):2471-7.

3. Herath HM, Kulatunga A. Large hepatocellular carcinoma in a noncirrhotic liver with peritoneal and omental metastasis in a healthy man: a case report. J Med Case Rep. 2017;11(1):34.

4. Sharma SK, Mohan A. Extrapulmonary tuberculosis. Indian J Med Res. 2004;120(4):316-53.

5. Javier RT, Butel JS. The history of tumor virology. Cancer Res. 2008;68(19):7693-706.

6. Zur Hausen H. Oncogenic DNA viruses. Oncogene. 2001;20(54):7820-3.

7. Bayle GL. Recherches sur la phthisie pulmonaire: ouvrage lu à la Société de la faculté de médecine de Paris, dans diverses séances, en 1809 et 1810: Gabon; 1810.

8. Wagner E. Die Struktur des Leberkrebs. Arch Heilk. 1861;2:209-29.

9. Falagas ME, Kouranos VD, Athanassa Z, Kopterides P. Tuberculosis and malignancy. QJM. 2010;103(7):461-87.

10. Shin DM, Yang CS, Lee JY, Lee SJ, Choi HH, Lee HM, Yuk JM, Harding CV, Jo EK. Mycobacterium tuberculosis lipoprotein-induced association of TLR2 with protein kinase $C \zeta$ in lipid rafts contributes to reactive oxygen species-dependent inflammatory signalling in macrophages. Cell Microbiol. 2008;10(9):1893-905.

11. Velmurugan $K$, Chen B, Miller JL, Azogue S, Gurses S, Hsu T, Glickman M, Jacobs WR Jr, Porcelli SA, Briken V. Mycobacterium tuberculosis nuoG is a virulence gene that inhibits apoptosis of infected host cells. PLoS Pathog. 2007;3(7):e110.

12. Matsuyama W, Kubota R, Hashiguchi T, Momi H, Kawabata M, Nakagawa M, Arimura K, Osame M. Purified protein derivative of tuberculin upregulates the expression of vascular endothelial growth factor in T lymphocytes in vitro. Immunology. 2002;106(1):96-101.

13. Multhoff G, Molls M, Radons J. Chronic inflammation in cancer development. Front Immunol. 2012;2:98-98. 
14. Cheng VC, Yam WC, Hung IF, Woo PC, Lau SK, Tang BS, Yuen KY. Clinical evaluation of the polymerase chain reaction for the rapid diagnosis of tuberculosis. J Clin Pathol. 2004;57(3):281-5.

15. Hennedige T, Venkatesh SK. Imaging of hepatocellular carcinoma: diagnosis, staging and treatment monitoring. Cancer Imaging. 2013;12(3):530-47.

16. Lee JH, Lee JM, Kim SJ, Baek JH, Yun SH, Kim KW, Han JK, Choi BI. Enhancement patterns of hepatocellular carcinomas on multiphasicmultidetector row CT: comparison with pathological differentiation. Br J Radiol. 2012;85(1017):e573-583.

17. Patnaik M, Liegmann K, Peter JB. Rapid detection of smear-negative Mycobacterium tuberculosis by PCR and sequencing for rifampin resistance with DNA extracted directly from slides. J Clin Microbiol. 2001;39(1):51-2.

18. Sheu JC, Sung JL, Chen DS, Yang PM, Lai MY, Lee CS, Hsu HC, Chuang CN, Yang PC, Wang TH, et al. Growth rate of asymptomatic hepatocellular carcinoma and its clinical implications. Gastroenterology. 1985;89(2):259-66.

19. Schwartz M. A biomathematical approach to clinical tumor growth. Cancer. 1961;14(6):1272-94.

\section{Publisher's Note}

Springer Nature remains neutral with regard to jurisdictional claims in published maps and institutional affiliations.
Ready to submit your research? Choose BMC and benefit from:

- fast, convenient online submission

- thorough peer review by experienced researchers in your field

- rapid publication on acceptance

- support for research data, including large and complex data types

- gold Open Access which fosters wider collaboration and increased citations

- maximum visibility for your research: over $100 \mathrm{M}$ website views per year

At BMC, research is always in progress.

Learn more biomedcentral.com/submissions 